\title{
PERKEMBANGAN ANTROPOLOGI HUKUM DALAM SUDUT PANDANG PLURALISME HUKUM
}

\author{
ZAKIRURAHMAN \\ Email : Zakirurahman69@gmail.com \\ No. BP : 2110003600379 \\ UNIVERITAS EKASAKTI PADANG
}

\section{PENDAHULUAN}

\section{A. Latar Belakang}

Seorang filsuf China; Lao Chai, pernah berkata bahwa suatu perjalanan yang bermil-mil jauhnya dimulai dengan hanya satu langkah. Langkah manusia yang disebut filsuf itu tak lain adalah antropologi. Benda apa yang disebut dengan Antropologi itu? Beberapa atau bahkan banyak orang mungkin sudah pernah mendengarnya. Beberapa orang mungkin mempunyai ide-ide tentang Antropologi yang didapat melalui berbagai media baik media cetak maupun media elektronik. Beberapa orang lagi bahkan mungkin sudah pernah membaca literature-literature atau tulisan-tulisan tentang Antropologi.

Banyak orang berpikir bahwa para ahli Antropologi adalah ilmuwan yang hanya tertarik pada peninggalan-peninggalan masa lalu; Antroplogi bekerja menggali sisa-sisa kehidupan masa lalu untuk mendapatkan pecahan guci-guci tua, peralatan -peralatan dari batu dan kemudian mencoba memberi arti dari apa yang ditemukannya itu. Pandangan yang lain mengasosiasikan Antropologi dengan teori Evolusi dan mengenyampingkan kerja dari Sang Pencipta dalam mempelajari kemunculan dan perkembangan mahluk manusia. Masyarakat yang mempunyai pandangan yang sangat keras terhadap penciptaan manusia dari sudut agama kemudian melindungi bahkan melarang anak-anak mereka dari Antroplogi dan doktrin-doktrinnya. Bahkan masih banyak orang awam yang berpikir kalau Antropologi itu bekerja atau meneliti orang- 
orang yang aneh dan eksotis yang tinggal di daerah-daerah yang jauh dimana mereka masih menjalankan kebiasaan-kebiasaan yang bagi masyarakat umum adalah asing.

Semua pandangan tentang ilmu Antroplogi ini pada tingkat tertentu ada benarnya, tetapi seperti ada cerita tentang beberapa orang buta yang ingin mengetahui bagaimana bentuk seekor gajah dimana masing-masing orang hanya meraba bagian-bagian tertentu saja sehingga anggapan mereka tentang bentuk gajah itupun menjadi bermacam-macam, terjadi juga pada Antropologi. Pandangan yang berdasarkan informasi yang sepotongsepotong ini mengakibatkan kekurang pahaman masyarakat awam tentang apa sebenarnya Antropologi itu. Antropologi memang tertarik pada masa lampau. Mereka ingin tahu tentang asal-mula manusia dan perkembangannya, dan mereka juga mempelajari masyarakat-masyarakat yang masih sederhana (sering disebut dengan primitif). Tetapi sekarang Antropologi juga mempelajari tingkah-laku manusia di tempat-tempat umum seperti di restaurant, rumah-sakit dan di tempat-tempat bisnis modern lainnya. Mereka juga tertarik dengan bentuk-bentuk pemerintahan atau negara modern yang ada sekarang ini sama tertariknya ketika mereka mempelajari bentukbentuk pemerintahan yang sederhana yang terjadi pada masa lampau atau masih terjadi pada masyarakat-masyarakat di daerah yang terpencil.

\section{B. Rumusan Masalah}

Berdasarkan penjelasan pada latar belakang di atas, maka permasalahan yang akan dibahas dalam makalah ini adalah bagaimana perkembangan antropologi dalam kaitannya dengan sudut pandang hukum.

\section{Tujuan}

Tujuan penulisan makalah ini adalah untuk mengetahui bagaimana perkembangan antropologi dalam kaitannya dengan sudut pandang hukum.

\section{Manfaat}


Adapun manfaat penulisan makalah ini adalah sebagai wadah bagi kami untuk mengembangkan wawasan yang berkaitan dengan perkembangan antropologi dalam kaitannya dengan sudut pandang hukum.

\section{PEMBAHASAN}

\section{A. Perkembangan Antropologi}

Seperti halnya Sosiologi, Antropologi sebagai sebuah ilmu juga mengalami tahapan-tahapan dalam perkembangannya. Koentjaraninggrat menyusun perkembangan ilmu Antropologi menjadi empat fase sebagai berikut:

1. Fase Pertama (Sebelum tahun 1800-an)

Sekitar abad ke-15-16, bangsa-bangsa di Eropa mulai berlomba-lomba untuk menjelajahi dunia. Mulai dari Afrika, Amerika, Asia, hingga ke Australia. Dalam penjelajahannya mereka banyak menemukan hal-hal baru. Mereka juga banyak menjumpai suku-suku yang asing bagi mereka. Kisah-kisah petualangan dan penemuan mereka kemudian mereka catat di buku harian ataupun jurnal perjalanan. Mereka mencatat segala sesuatu yang berhubungan dengan suku-suku asing tersebut. Mulai dari ciri-ciri fisik, kebudayaan, susunan masyarakat, atau bahasa dari suku tersebut. Bahan-bahan yang berisi tentang deskripsi suku asing 
tersebut kemudian dikenal dengan bahan etnogragfi atau deskripsi tentang bangsa-bangsa.

Bahan etnografi itu menarik perhatian pelajar-pelajar di Eropa. Kemudian, pada permulaan abad ke-19 perhatian bangsa Eropa terhadap bahan-bahan etnografi suku luar Eropa dari sudut pandang ilmiah, menjadi sangat besar. Karena itu, timbul usaha-usaha untuk mengintegrasikan seluruh himpunan bahan etnografi.

2. Fase Kedua (tahun 1800-an)

Pada fase ini, bahan-bahan etnografi tersebut telah disusun menjadi karangankarangan berdasarkan cara berpikir evolusi masyarakat pada saat itu. masyarakat dan kebudayaan berevolusi secara perlahan-lahan dan dalam jangka waktu yang lama. Mereka menganggap bangsa-bangsa selain Eropa sebagai bangsa-bangsa primitif yang tertinggal, dan menganggap Eropa sebagai bangsa yang tinggi kebudayaannya

Pada fase ini, Antopologi bertujuan akademis, mereka mempelajari masyarakat dan kebudayaan primitif dengan maksud untuk memperoleh pemahaman tentang tingkat-tingkat sejarah penyebaran kebudayaan manusia.

3. Fase Ketiga (awal abad ke-20)

Pada fase ini, negara-negara di Eropa berlomba-lomba membangun koloni di benua lain seperti Asia, Amerika, Australia dan Afrika. Dalam rangka membangun koloni-koloni tersebut, muncul berbagai kendala seperti serangan dari bangsa asli, pemberontakan-pemberontakan, cuaca yang kurang cocok bagi bangsa Eropa serta hambatan-hambatan lain. Dalam menghadapinya, pemerintahan kolonial negara Eropa berusaha mencari-cari kelemahan suku asli untuk kemudian menaklukannya. Untuk itulah mereka mulai mempelajari bahanbahan etnografi tentang suku-suku bangsa di luar Eropa, mempelajari kebudayaan dan kebiasaannya, untuk kepentingan pemerintah kolonial.

4. Fase Keempat (setelah tahun 1930-an)

Pada fase ini, Antropologi berkembang secara pesat. Kebudayaan-kebudayaan suku bangsa asli yang di jajah bangsa Eropa, mulai hilang akibat terpengaruh kebudayaan bangsa Eropa. 
Pada masa ini pula terjadi sebuah perang besar di Eropa, Perang Dunia II. Perang ini membawa banyak perubahan dalam kehidupan manusia dan membawa sebagian besar negara-negara di dunia kepada kehancuran total. Kehancuran itu menghasilkan kemiskinan, kesenjangan sosial, dan kesengsaraan yang tak berujung.

Namun pada saat itu juga, muncul semangat nasionalisme bangsa-bangsa yang dijajah Eropa untuk keluar dari belenggu penjajahan. Sebagian dari bangsabangsa tersebut berhasil mereka. Namun banyak masyarakatnya yang masih memendam dendam terhadap bangsa Eropa yang telah menjajah mereka selama bertahun-tahun.

Proses-proses perubahan tersebut menyebabkan perhatian ilmu antropologi tidak lagi ditujukan kepada penduduk pedesaan di luar Eropa, tetapi juga kepada suku bangsa di daerah pedalaman Eropa seperti suku bangsa Soami, Flam dan Lapp.

Dalam kenyataannya, Antropologi mempelajari semua mahluk manusia yang pernah hidup pada semua waktu dan semua tempat yang ada di muka bumi ini. Mahluk manusia ini hanyalah satu dari sekian banyak bentuk mahluk hidup yang ada di bumi ini yang diperkirakan muncul lebih dari 4 milyar tahun yang lalu.

Antropologi bukanlah satu satunya ilmu yang mempelajari manusia. Ilmu-ilmu lain seperti ilmu Politik yang mempelajari kehidupan politik manusia, ilmu Ekonomi yang mempelajari ekonomi manusia atau ilmu Fisiologi yang mempelajari tubuh manusia dan masih banyak lagi ilmuilmu lain, juga mempelajari manusia. Tetapi ilmuilmu ini tidak mempelajari atau melihat manusia secara menyeluruh atau dalam ilmu Antropologi disebut dengan Holistik, seperti yang dilakukan oleh Antropologi. Antropologi berusaha untuk melihat segala aspek dari diri mahluk manusia pada semua waktu dan di semua tempat, seperti: Apa yang secara umum dimiliki oleh semua manusia? Dalam hal apa saja mereka itu berbeda? Mengapa mereka bertingkah-laku seperti itu? Ini semua adalah beberapa contoh pertanyaan mendasar dalam studi-studi Antropologi. 


\section{B. Antropologi Sosial-Budaya}

Antropologi Sosial-Budaya atau lebih sering disebut Antropologi Budaya berhubungan dengan apa yang sering disebut dengan Etnologi. Ilmu ini mempelajari tingkah-laku manusia, baik itu tingkah-laku individu atau tingkah laku kelompok. Tingkah-laku yang dipelajari disini bukan hanya kegiatan yang bisa diamati dengan mata saja, tetapi juga apa yang ada dalam pikiran mereka. Pada manusia, tingkah-laku ini tergantung pada proses pembelajaran. Apa yang mereka lakukan adalah hasil dari proses belajar yang dilakukan oleh manusia sepanjang hidupnya disadari atau tidak. Mereka mempelajari bagaimana bertingkah-laku ini dengan cara mencontoh atau belajar dari generasi diatasnya dan juga dari lingkungan alam dan sosial yang ada disekelilingnya. Inilah yang oleh para ahli Antropologi disebut dengan kebudayaan. Kebudayaan dari kelompok-kelompok manusia, baik itu kelompok kecil maupun kelompok yang sangat besar inilah yang menjadi objek spesial dari penelitian-penelitian Antropologi Sosial Budaya. Dalam perkembangannya Antropologi Sosial-Budaya ini memecah lagi kedalam bentuk-bentuk spesialisasi atau pengkhususan disesuaikan dengan bidang kajian yang dipelajari atau diteliti. Antroplogi Hukum yang mempelajari bentuk-bentuk hukum pada kelompok-kelompok masyarakat atau Antropologi Ekonomi yang mempelajari gejala-gejala serta bentuk-bentuk perekonomian pada kelompokkelompok masyarakat adalah dua contoh dari sekian banyak bentuk spesialasi dalam Antropologi Sosial-Budaya.

Kebudayaan yang dimiliki oleh manusia juga dimiliki dengan cara belajar. Dia tidak diturunkan secara bilogis atau pewarisan melalui unsur genetis. Hal ini perlu ditegaskan untuk membedakan perilaku manusia yang digerakan oleh kebudayaan dengan perilaku mahluk lain yang tingkah-lakunya digerakan oleh insting.

Ketika baru dilahirkan, semua tingkah laku manusia yang baru lahir tersebut digerakkan olen insting dan naluri. Insting atau naluri ini tidak termasuk dalam kebudayaan, tetapi mempengaruhi kebudayaan. Contohnya adalah kebutuhan akan makan. Makan adalah kebutuhan dasar yang tidak termasuk dalam kebudayaan. Tetapi bagaimana kebutuhan itu dipenuhi; apa yang dimakan, bagaimana cara memakan adalah bagian dari kebudayaan. Semua manusia perlu makan, tetapi kebudayaan yang berbeda 
dari kelompok-kelompoknya menyebabkan manusia melakukan kegiatan dasar itu dengan cara yang berbeda. Contohnya adalah cara makan yang berlaku sekarang. Pada masa dulu orang makan hanya dengan menggunakan tangannya saja, langsung menyuapkan makanan kedalam mulutnya, tetapi cara tersebut perlahan lahan berubah, manusia mulai menggunakan alat yang sederhana dari kayu untuk menyendok dan menyuapkan makanannya dan sekarang alat tersebut dibuat dari banyak bahan. Begitu juga tempat dimana manusia itu makan. Dulu manusia makan disembarang tempat, tetapi sekarang ada tempat-tempat khusus dimana makanan itu dimakan. Hal ini semua terjadi karena manusia mempelajari atau mencontoh sesuatu yang dilakukan oleh generasi sebelumya atau lingkungan disekitarnya yang dianggap baik dan berguna dalam hidupnya.

Sebaliknya kelakuan yang didorong oleh insting tidak dipelajari. Semut semut yang dikatakan bersifat sosial tidak dikatakan memiliki kebudayaan, walaupun mereka mempunyai tingkah-laku yang teratur. Mereka membagi pekerjaannya, membuat sarang dan mempunyai pasukan penyerbu yang semuanya dilakukan tanpa pernah diajari atau tanpa pernah meniru dari semut yang lain. Pola kelakuan seperti ini diwarisi secara genetis.

\section{Pengaruh Budaya Dalam Perkembangan Antropologi}

Agar dapat dikatakan sebagai suatu kebudayaan, kebiasaan-kebiasaan seorang individu harus dimiliki bersama oleh suatu kelompok manusia. Para ahli Antropologi membatasi diri untuk berpendapat suatu kelompok mempunyai kebudayaan jika para warganya memiliki secara bersama sejumlah pola-pola berpikir dan berkelakuan yang sama yang didapat melalui proses belajar.

Suatu kebudayaan dapat dirumuskan sebagai seperangkat kepercayaan, nilai-nilai dan cara berlaku atau kebiasaan yang dipelajari dan yang dimiliki bersama oleh para warga dari suatu kelompok masyarakat. Pengertian masyarakat sendiri dalam 
Antropologi adalah sekelompok orang yang tinggal di suatu wilayah dan yang memakai suatu bahasa yang biasanya tidak dimengerti oleh penduduk tetangganya.

Dalam setiap masyarakat, oleh para anggotanya dikembangkan sejumlah pola-pola budaya yang ideal dan pola-pola ini cenderung diperkuat dengan adanya pembatasanpembatasan kebudayaan. Pola-pola kebudayaan yang ideal itu memuat hal-hal yang oleh sebagian besar dari masyarakat tersebut diakui sebagai kewajiban yang harus dilakukan dalam keadaan-keadaan tertentu. Pola-pola inilah yang sering disebut dengan normanorma, Walaupun kita semua tahu bahwa tidak semua orang dalam kebudayaannya selalu berbuat seperti apa yang telah mereka patokkan bersama sebagai hal yang ideal tersebut. Sebab bila para warga masyarakat selalu mematuhi dan mengikuti normanorma yang ada pada masyarakatnya maka tidak akan ada apa yang disebut dengan pembatasan-pembatasan kebudayaan. Sebagian dari pola-pola yang ideal tersebut dalam kenyataannya berbeda dengan perilaku sebenarnya karena pola-pola tersebut telah dikesampingkan oleh cara-cara yang dibiasakan oleh masyarakat. 


\section{PENUTUP}

\section{A. Kesimpulan}

Antropologi adalah salah satu cabang ilmu pengetahuan sosial yang mempelajari tentang budaya masyarakat suatu etnis tertentu. Antropologi lahir atau muncul berawal dari ketertarikan orang-orang Eropa yang melihat ciri-ciri fisik, adat istiadat, budaya yang berbeda dari apa yang dikenal di Eropa. Terbentuklah ilmu antropologi dengan melalui beberapa fase. Antropologi lebih memusatkan pada penduduk yang merupakan masyarakat tunggal, tunggal dalam arti kesatuan masyarakat yang tinggal daerah yang sama, antropologi mirip seperti sosiologi tetapi pada sosiologi lebih menitik beratkan pada masyarakat dan kehidupan sosialnya. Perkembangan antropologi terdiri atas 4 tahap yaitu ; 1)

$>$ Fase Pertama (Sebelum tahun 1800-an) 
Sekitar abad ke-15-16, bangsa-bangsa di Eropa mulai berlomba-lomba untuk menjelajahi dunia. Mulai dari Afrika, Amerika, Asia, hingga ke Australia. Dalam penjelajahannya mereka banyak menemukan hal-hal baru. Mereka juga banyak menjumpai suku-suku yang asing bagi mereka. Kisah-kisah petualangan dan penemuan mereka kemudian mereka catat di buku harian ataupun jurnal perjalanan.

Fase Kedua (tahun 1800-an)

Pada fase ini, bahan-bahan etnografi tersebut telah disusun menjadi karangankarangan berdasarkan cara berpikir evolusi masyarakat pada saat itu. masyarakat dan kebudayaan berevolusi secara perlahan-lahan dan dalam jangka waktu yang lama. Mereka menganggap bangsa-bangsa selain Eropa sebagai bangsa-bangsa primitif yang tertinggal, dan menganggap Eropa sebagai bangsa yang tinggi kebudayaannya.

Fase Ketiga (awal abad ke-20)

Pada fase ini, negara-negara di Eropa berlomba-lomba membangun koloni di benua lain seperti Asia, Amerika, Australia dan Afrika. Dalam rangka membangun koloni-koloni tersebut, muncul berbagai kendala seperti serangan dari bangsa asli, pemberontakan-pemberontakan, cuaca yang kurang cocok bagi bangsa Eropa serta hambatan-hambatan lain.

Fase Keempat (setelah tahun 1930-an)

Pada fase ini, Antropologi berkembang secara pesat. Kebudayaan-kebudayaan suku bangsa asli yang dijajah bangsa Eropa, mulai hilang akibat terpengaruh kebudayaan bangsa Eropa.

\section{B. Saran}

Antropologi sangat besar peranannya dalam perkembangan kehidupan manusia sehingga diharapkan kepada kita semua untuk selalu mengembangkan wawasan dan 
memperdalam pemahaman tentang kehidupan masyarakat yang berkaitan dengan antropologi. 


\section{DAFTAR PUSTAKA}

Green, E.C 1986 Practicing Development Anthropology. Boulder and London: Westview

Leonard Seregar. 2002. Antorpologi dan Konsep Kebudayaan. Universitas Cendrawasih Press. Jayapura.

Masinambow, E.K.M (Ed) 1997 Koentjaraningrat dan Antropologi di Indonesia, Jakarta: Asosiasi Antropologi Indonesia dan Yayasan Obor Indonesia.

Rhoades, R.E 1986 Breaking New Ground: Agricultural Anthropology. Dalam: Green Ed.

Suparlan, Pasurdi 1995 Antropologi dalam Pembangunan. Jakarta: UI Press 